\title{
PARTICULATES IN ACIDIC SNOWS FROM THE CAIRNGORMS, SCOTLAND
}

by

\author{
M. Tranter, P. Brimblecombe, T.D. Davies, P.W. Abrahams, I. Blackwood, A. Fernandes and C.E. Vincent
}

(School of Environmental Sciences, University of East Anglia, Norwich NR4 7TJ, England)

The most severe acidic deposition event in a small, remote, high-altitude catchment in the Cairngorm Mountains, Scotland (Brimblecombe and others 1985), during the period from January to May 1984, was a snowfall of $\mathrm{pH} 3.0$, characterized by its distinctive black appearance (Davies and others 1984). The particulate loading of the snowfall was around $0.01 \mathrm{~g}^{-1}$ of melted snow, and the particulates consisted of a large proportion of pulverized fuel ash and black carbonaceous residue. High concentrations of $\mathrm{Pb}, \mathrm{Mn}$ and $\mathrm{Zn}$ were found in the particulates $(1530,4960$ and $9830 \mathrm{ppm}$ respectively). The solute load of the snow-melt was predominantly $\mathrm{H}^{+}, \mathrm{Cl}^{-}, \mathrm{NO}_{3}^{-}$and $\mathrm{SO}_{4}^{2-}$, with small amounts of the other major cations. Acetate and perhaps methane sulphonic acid have also been detected. Of particular interest is the molar ratio of non-sea-salt sulphate : non-sea-salt chloride : nitrate, which was $1.04: 1.00$ : 1.71. Transport in association with an inversion layer at 1000 to $1500 \mathrm{~m}$ is likely to be the mechanism by which heavily polluted air reached the catchment from several hundred kilometres to the south. Cycling of air through cumulus circulations may have led to large volumes of air containing high particulate concentrations becoming available for scavenging by snow.
Other snowfalls of low $\mathrm{pH}(3.5,3.6,3.6)$ also appear to have been associated with heavier and darker particulate loadings, while the least acidic snowfalls $(\mathrm{pH} 4.5,4.6,4.8)$ have been associated with low particulate loadings, which are pale grey in appearance. Investigations are underway to determine the relationship between $\mathrm{pH}$ and the carbonaceous content/particulate loading, to examine elemental compositions and to perform trajectory analysis of all snowfalls monitored in order to determine likely source regions for the pollution and to determine the transport mechanisms.

\section{REFERENCES}

Brimblecombe P, Tranter M, Abrahams P W, Blackwood I, Davies T D, Vincent C E 1985 Relocation and preferential elution of acidic solute through the snowpack of a small, remote, high-altitude Scottish catchment. Annals of Glaciology 7: 141-147

Davies T D, Abrahams P W, Tranter M, Blackwood I, Brimblecombe P, Vincent C E 1984 Black acidic snow in the remote Scottish highlands. Nature 312(5989): $58-61$ 